Dept. of Nutrition and Clinical Nutrition,

Faculty of Veterinary Medicine, Assiut University, Assiut, Egypt.

E-mail: abdelrheem@yahoo.com

\title{
EFFECTS OF AUTOCLAVED YEAST CULTURES (SACCHAROMYCES CEREVISIAE) AND LIVE YEAST ON RUMINAL FERMENTATION IN VITRO
}

(With 7 Tables and One Figure)

\author{
By \\ SH.M. ABDEL-RAHEEM, WAGEHA A. AWAD*, \\ C. IBEN** and J. BÖHM** \\ *Dept. of Animal Hygiene, South Valley University, Qena, Egypt. \\ **Institute of Animal Nutrition, Dept. of Farm Animals and Veterinary Public \\ Health, University of Veterinary Medicine, Vienna, Austria \\ (Received at 26/11/2011)

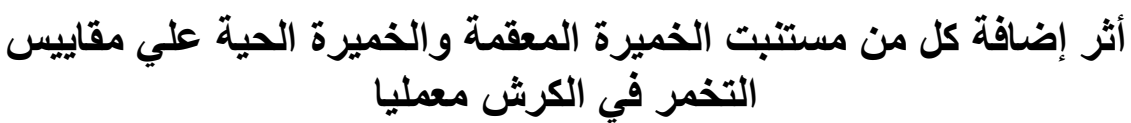 \\ شريف محد عبل الرحيم ، وجيهة عوض ، كرستينا إبين ، بيوسف بم

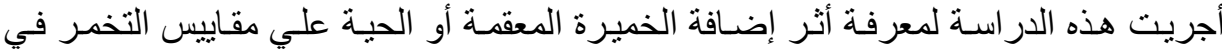

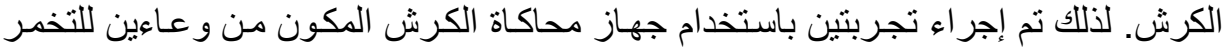

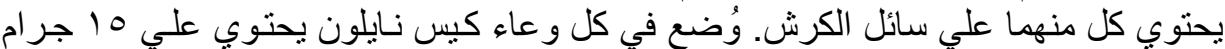

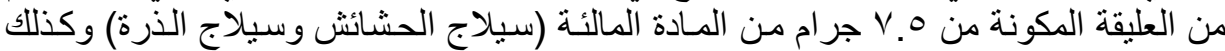

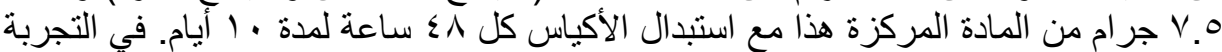

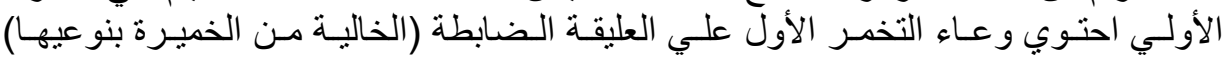

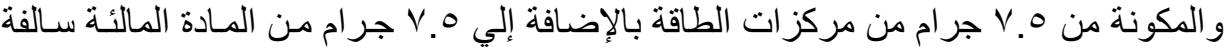

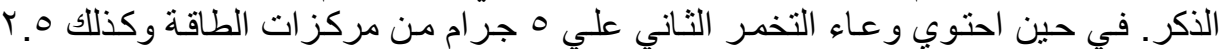

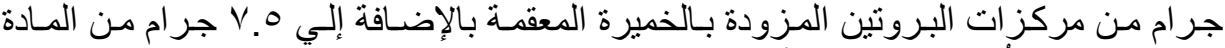

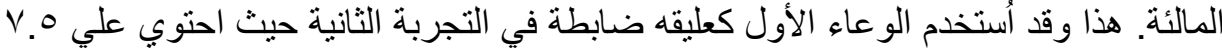

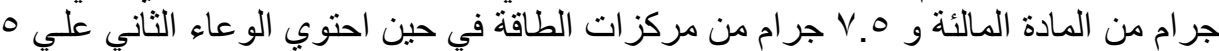

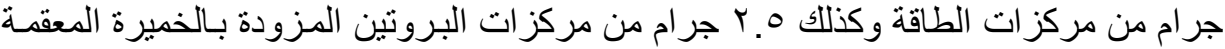

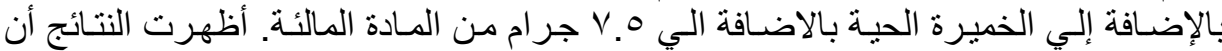

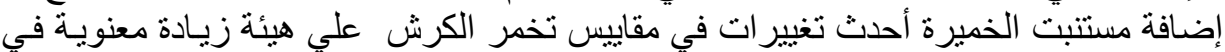

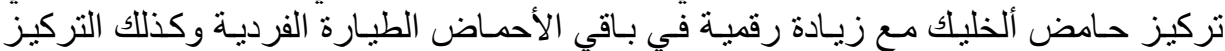

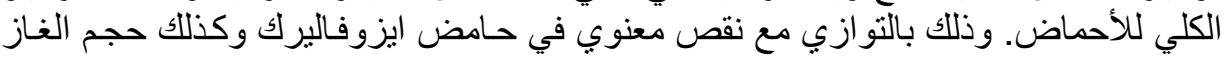




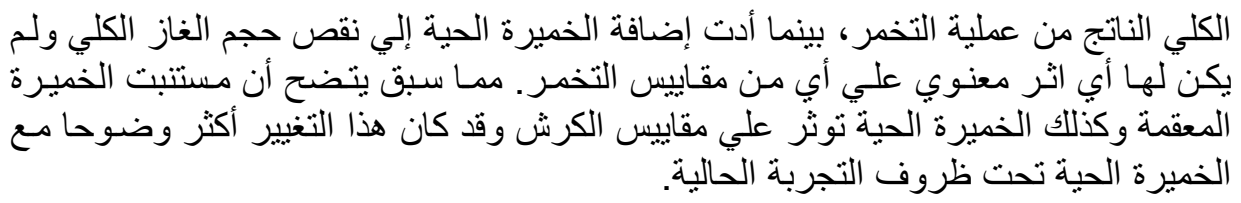

\section{SUMMARY}

The objective of this study is to determine whether an autoclaved yeast culture of Saccharomyces cerevisiae or live yeast has an effect on the parameters of ruminal fermentation. For this purpose, autoclaved yeast cultures and live yeast were tested simultaneously by the rumen simulation technique (Rusitec). Each fermentation vessel received daily $15 \mathrm{~g}$ feed bag consists of $7.5 \mathrm{~g}$ dried basal feed ( $5 \mathrm{~g}$ grass silage $+2.5 \mathrm{~g}$ corn silage) and $7.5 \mathrm{~g}$ concentrate pellets. Two experiments with two fermentation vessels were carried out. In exp 1 the $1^{\text {st }}$ vessel (control) received $7.5 \mathrm{~g}$ energy concentrate in addition to $7.5 \mathrm{~g}$ dried basal feed. The second fermentation vessel (T1) received $5 \mathrm{~g}$ energy concentrate plus $2.5 \mathrm{~g}$ protein concentrate containing autoclaved yeast culture in addition $7.5 \mathrm{~g}$ basal feed. In exp 2 the vessel 1 received the same control diet as in experiment one, while vessel 2 (T2) received 5 g energy concentrate $+2.5 \mathrm{~g}$ of protein concentrate containing autoclaved yeast culture and live yeast in addition to $7.5 \mathrm{~g}$ basal feed. Yeast culture influenced the ruminal fermentation kinetics in terms of lower $(\mathrm{P}<0.05)$ gas volume and higher acetate (mol \%), with a concomitant decrease in iso-valerate $(\mathrm{mol} \%)$ in experiment 1 , moreover, yeast culture numerically not statistically increase individual and total volatile fatty acids. in experiment 2 , the living yeast cells decreased gas volume more than yeast culture but not alter any other rumen fermentation kinetics. In conclusion autoclaved yeast culture and living yeast cells had beneficial effects on rumen fermentation and this effect was more pronounced with live yeast culture.

Key words: Autoclaved yeast culture, live yeast, Rusitec, fermentation parameters 


\section{INTRODUCTION}

Addition of Saccharomyces cerevisiae cultures to ruminant diets improved the digestibility of dry matter, crude protein, and hemicellulose; increased ruminal bacterial numbers; decreased ruminal lactate concentrations; and increased milk production of cows in early lactation (Gomez-Alarcon et al., 1990). Saccharomyces cerevisiae cultures provide soluble growth factors (i.e., organic acids, B vitamins, and amino acids) that are required by ruminal bacteria for growth on lactate (Nisbet and Martin, 1991). Dietary supplements of yeast culture, based on dried Saccharomyces cerevisiae, have been reported to increase productivity in ruminants, by a mechanism that results in an increased viable count of bacteria in the rumen which may lead to improved protein flow to the small intestine (Newbold 1995). Nisbet and Martin (1991) reported that $S$. cerevisiae stimulated the growth of the prominent lactic acid-utilizing rumen bacterium, Selenomonas ruminantium, in pure culture, apparently because dicarboxylic acids in the yeast stimulated lactate uptake by the bacterium. Moreover, Newbold et al. (1996) suggested two modes of action of yeast in stimulating rumen fermentation; the first, yeast respiratory activity protects anaerobic rumen bacteria from damage by oxgen, the second, yeast provides malic and other dicarboxylic acids which stimulate the growth of some rumen bacteria. They concluded that the stimulation of rumen bacteria by S. cerevisiae is at least partly dependent on its respiratory activity, and is not mediated by malic acid. Ruminal digestion of low quality feedstuffs provides the host volatile fatty acids and microbial protein to support energy requirements for sustenance, growth and work. Only about 10$35 \%$ of dietary energy consumed by the ruminant is conserved, however, improvements in digestive efficiency could improve ruminant animal production, with lowering input costs and undesired environmental impacts (Varga and Kolver, 1997). Ruminal methane production, for instance, results in the inefficient conversion of potentially energyyielding substrates into a form that can not be conserved by the host. There have been many attempts to manipulate the rumen fermentation with the intention of increasing the production of propionate and reducing the production of methane. There are advantages in both directions, since the production of methane represents a direct loss of energy, while propionic acid is an important precursor for gluconeogenesis. 
The rumen simulation technique (Rusitec) makes it possible to examine the direct effects of autoclaved yeast cultures or live yeast as additives in ruminant diets independent of the host ruminant. Therefore, the objective of this study was to investigate the effect of two types of yeast (autoclaved or live) on rumen fermentation parameters in vitro.

\section{MATERIALS and METHODS}

The experimental design is illustrated in Table 1. Two experiments were carried out using two Rusitec fermentation vessels described by Czerkawski and Breckenridge (1977). The incubation vessels was filled with rumen fluid. Rumen contents were taken from a rumen of fistulated cow that was maintained on a diet of grass hay and grain concentrates. Animals had free access to hay, water, and a vitaminenriched salt lick. Each vessel was loaded with 2 nylon bags. The nylon bags $(70 \times 120 \mathrm{~mm})$ had a pore size of $150 \mu \mathrm{m}$ which is usually used for in vitro rumen fermentation studies (Öztürk, 2003). At the start of the trial, one bag was filled with $80 \mathrm{~g}$ of solid rumen contents to inoculate particle-associated microorganisms into the system and the other with the daily tested diets. The nylon bag with solid rumen contents was replaced after $24 \mathrm{~h}$ of incubation with a bag containing the diet. The feed bag was changed after $48 \mathrm{~h}$ so that 2 bags were always present. This gave a retention time of $48 \mathrm{~h}$ for feed. Bags were exchanged under anaerobic conditions using $\mathrm{N} 2$ to flush the incubation vessels. To maintain conditions as close to those of the in vivo rumen as possible, the incubation temperature was $39^{\circ} \mathrm{C}$ and rumen fluid turnover was simulated by modified artificial saliva. By moving the inner vessel up and down continuously rumen motility was simulated and exchange between the fluid and particle phases was completely done. In both experiments each vessel received $7.5 \mathrm{~g}$ dried basal feed $(5 \mathrm{~g}$ grass silage $+2.5 \mathrm{~g}$ corn silage) and $7.5 \mathrm{~g}$ concentrate. In exp 1 the $1^{\text {st }}$ vessel (control) received $7.5 \mathrm{~g}$ of energy concentrate (kombilac 16) beside $7.5 \mathrm{~g}$ of the basal feed, while the second fermentation vessel (T1) received a concentrate mixture consisting of $5 \mathrm{~g}$ energy concentrate (Kombilac 16) and $2.5 \mathrm{~g}$ protein concentrate containing $2.47 \%$ autoclaved yeast culture (Rumenac Prolactin) in addition to $7.5 \mathrm{~g}$ basal feed. In Exp. 2 vessel 1 received the same control diet as in experiment 1 , however, vessel 2 received $5 \mathrm{~g}$ of energy concentrate plus $2.5 \mathrm{~g}$ protein concentrate containing autoclaved yeast (Rumenac Prolactin) in addition to a feed 
additives containing live yeast (Rumex SC) beside the basal feed. The chemical composition of the experimental diets is presented in Table 2. An equilibration period of 5 days was allowed before the rumen fluid and the effluent samples were collected for the next 5 days (collection period) and repeated 3 times, and sequential samples of ruminal fluid were taken from inside the vessels before replacing the feed bags. Gas volume was determined daily by gas bag. The liquid flow through the vessels was maintained by continuous infusion of a buffer solution $(\mathrm{pH}$ 7.4 ) at the rate of $750 \mathrm{ml} /$ day the composition of the buffer is shown in Table 3 according to McDougall's (1948). All additives were supported by Fixkraft ${ }^{\circledR}$ company (Enns, Austria) except Rumex SC was supported by Delacon company ${ }^{\circledR}$, Austria.

\section{Analytical procedures and samplings}

Most of the analytical procedures used were as described by Czerkawski and Breckenridge (1977). The $\mathrm{pH}$ and redox potential values were measured daily in each vessel at the time of feeding using a $\mathrm{pH}$ and redox electrodes (Typ 408, Mettler Toledo, Steinbach, Germany) connected to a Knick pH meter (digital pH meter 646, Knick, Berlin, Germany). Liquid effluent was collected daily and samples were taken for analyses of microbial particulate DM. Rumen fluid samples was mixed with oxalic acid $(0.1 \mathrm{~mol} / \mathrm{l})$, sodium azide $(40 \mathrm{mmol} / \mathrm{l})$ and capronic acid $(0.1 \mathrm{mmol} / \mathrm{l})$ as internal standard, centrifuged and the supernatant was analyzed for short chain fatty acids (SCFAs) by gas chromatography (Agilent $6890 \mathrm{~N} \mathrm{GC}$ ) equipped with a $30 \mathrm{~m}$ x $530 \mu \mathrm{m}$ x $0.1 \mu \mathrm{m}$ capillary column with flame ionization detector according to the method described by Schafer, (1995). Rumen ammonia was analysed using test kits (Sigma - Aldrich) by spectrophotometer (Hitachi, U3000, USA)

\section{Statistical analyses}

Statistical analyses were conducted with the Statistical Package for Social Science (SPSS for Windows Version 13; SPSS GmbH, Munich, Germany) to determine if the variables differed between groups. Differences between the means were compared by independent t-test. Probability values of $\mathrm{P}<0.05$ were considered as significant. Values in tables are means \pm SD. 


\section{RESULTS}

Effects of yeast culture on ruminal fermentation in vitro are shown in Tables 4, 5, 6 and 7. In experiment 1: the addition of autoclaved yeast culture in the fermentation vessel significantly decreased the gas volume and the molar proportion of isovalerate volatile fatty acid in concomitant with significant increase in the molar proportion of ruminal acetate. In addition, there are numerical increases in the effluent microbial dry matter out put (particulate dry matter, PDM), the concentration of propionate, other individuals and the total daily volatile fatty acids (VFA) by the addition of autoclaved yeast culture to the fermentation vessels. The autoclaved yeast culture exhibit no significant $(\mathrm{P}>0.05)$ impact on rumen $\mathrm{pH}$, redox potential and ammonia concentration in experiment 1 .

In experiment 2: a significant reduction in gas volume from vessel 2 receiving the living yeast cell in comparison with vessel receiving the control diet. In addition, there are numerical increases in the individual and total volatile fatty acids. No significant impact was noticed in experiment 2 on other rumen fermentation kinetics.

Table 1: Experimental design.

\begin{tabular}{|c|l|l|}
\hline Experiment & \multicolumn{1}{|c|}{ Vessel 1 } & \multicolumn{1}{c|}{ Vessel 2 } \\
\hline \multirow{5}{*}{1} & $\begin{array}{l}7.5 \text { g basal feed* } \\
\text { (roughages) } \\
7.5 \text { Energy Concentrate } \\
\text { (kombilac 16) } \\
\text { (control) }\end{array}$ & $\begin{array}{l}\text { 7.5 g basal feed (roughages) } \\
5 \mathrm{~g} \text { Energy Concentrates } \\
2.5 \text { g protein concentrate containing } \\
\text { autoclaved yeast culture (Ruminac } \\
\text { prolactin (T1) }\end{array}$ \\
\hline \multirow{2}{*}{2} & $\begin{array}{l}7.5 \text { g basal feed (roughages) } \\
7.5 \text { Energy } \\
\text { Concentrate(kombilac 16) } \\
\text { (control) }\end{array}$ & $\begin{array}{l}7.5 \text { g basal feed (roughages) } \\
5 \mathrm{~g} \text { Energy Concentrates } \\
2.5 \text { g protein concentrate containing } \\
\text { autoclaved yeast culture (Ruminac } \\
\text { prolactin + live yeast (Rumex SC) (T2) }\end{array}$ \\
\hline
\end{tabular}

$*$ Basal feed $=5 \mathrm{~g}$ grass silage $+2.5 \mathrm{~g}$ corn silage

Ruminac prolactin contains autoclaved yeast culture $(2.47 \%)$ 
Table 2: Chemical composition of the experimental diet $(\%$, as fed basis)

\begin{tabular}{|lcccccccc|}
\hline Item & DM & OM & CP & EE & CF & NFE & Ash & GE $^{1}$ \\
\hline Grass silage & 53.1 & 47.3 & 9.5 & 1 & 11.9 & 24.9 & 5.8 & 10.138 \\
Corn silage & 35.4 & 34.1 & 2.3 & 1.5 & 6.6 & 23.7 & 1.3 & 6.656 \\
Kombilac 16 & 87.6 & 82.7 & 16.9 & 3 & 5.3 & 57.5 & 4.9 & 14.857 \\
$\begin{array}{l}\text { Rumenac prolactin } \\
\text { Rumenac prolactin }\end{array}$ & 80 & 85 & 20.3 & 2.8 & 5.2 & 56.7 & 5 & 15.369 \\
$\begin{array}{l}\text { Rumex SC } \\
\text { + Rumb }\end{array}$ & 82.3 & 20.4 & 3.1 & 4.8 & 54 & 5.1 & 14.506 \\
\hline
\end{tabular}

${ }^{1} \mathrm{GE} \mathrm{KJ} / \mathrm{g}=$ Determined by bomb calorimeter

Kombilac 16= Energy concentrate contains $16 \%$ CP and 7 MJ NEL, Rumenac prolactin $=$ protein concentrate contains $20 \% \mathrm{CP}, 7.5 \mathrm{MJ}$ NEL and yeast culture $(2.47$ $\%$, Rumex $\mathrm{SC}=$ (natural feed additives) containing live yeast.

Table 3: Chemical composition of modified artificial saliva (RUSITEC buffer)

\begin{tabular}{|c|c|c|}
\hline Ingredient & $\mathrm{g} / 1$ & $\mathrm{mmol} / \mathrm{l}$ \\
\hline Sodium chloride $(\mathrm{NaCl})$ & 1.6380 & 28 \\
\hline Potassium chloride $(\mathrm{KCl})$ & 0.573 & 7.69 \\
\hline Calcium chloride $\left(\mathrm{CaCl}_{2} 2 \mathrm{H}_{2} \mathrm{O}\right)$ & 0.0323 & 0.22 \\
\hline Magnesium chloride $\left(\mathrm{Mg} \mathrm{Cl}_{2} 6 \mathrm{H}_{2} \mathrm{O}\right)$ & 0.128 & 0.63 \\
\hline Ammonium chloride $\left(\mathrm{NH}_{4} \mathrm{Cl}\right)$ & 0.267 & 5.00 \\
\hline Disodium hydrogen phosphate $\left(\mathrm{Na}_{2} \mathrm{HPO} 412 \mathrm{H}_{2} \mathrm{O}\right)$ & 3.58 & 10.00 \\
\hline Sodium Hydrogen phosphate $\left(\mathrm{NaH} 2 \mathrm{PO} 4 \mathrm{H}_{2} \mathrm{O}\right)$ & 1.38 & 10.00 \\
\hline Sodium bicarbonate $\left(\mathrm{NaHCO}_{3}\right)$ & 8.224 & 97.90 \\
\hline
\end{tabular}


Table 4: Effect of autoclaved yeast culture on rumen fermentation parameters in Rusitec (Exp.1)

\begin{tabular}{|lccc|}
\hline Items & Control & Autoclaved yeast culture & $\mathrm{P}$ \\
\hline $\mathrm{Ph}$ & $6.47 \pm 0.08$ & $6.45 \pm 0.04$ & 0.2 \\
Redox potential (mv) & $-286.5 \pm 19$ & $-281 \pm 21$ & 1.2 \\
Gas volume (ml) & $1263 \pm 84^{\mathrm{a}}$ & $1150 \pm 77^{\mathrm{b}}$ & 0.000 \\
Ammonia $(\mathrm{g} / \mathrm{l})$ & $0.20 \pm 0.05$ & $0.19 \pm 0.06$ & 0.8 \\
Effluent PDM (g/l) & $0.50 \pm 0.06$ & $0.71 \pm 0.14$ & 0.15 \\
\hline
\end{tabular}

${ }^{\mathrm{a}, \mathrm{b}}$ Means within a row with different superscripts are significantly different $(\mathrm{P}<005)$. $\mathrm{PDM}=$ particulate dry matter (microbial output)

Table 5: Effect of autoclaved yeast culture on rumen VFA and the molar \% VFA (Exp. 1)

\begin{tabular}{|lccc|}
\hline Acids & Control & Autoclaved yeast culture & $\mathrm{P}$ \\
\hline Acetate $(\mathrm{mmol} / \mathrm{l})$ & $19.4 \pm 2.1$ & $20.9 \pm 4.6$ & 0.18 \\
Propionate $(\mathrm{mmol} / \mathrm{l})$ & $7.8 \pm 0.6$ & $8.1 \pm 1.7$ & 0.4 \\
i-butyrate $(\mathrm{mmol} / \mathrm{l})$ & $0.27 \pm 0.03$ & $0.3 \pm 0.1$ & 0.25 \\
n-butyrate $(\mathrm{mmol} / \mathrm{l})$ & $6.10 \pm 0.6$ & $6.4 \pm 1.3$ & 0.18 \\
i-valerate $(\mathrm{mmol} / \mathrm{l})$ & $1.7 \pm 0.3$ & $1.5 \pm 0.3$ & 0.08 \\
n-valerate $(\mathrm{mmol} / \mathrm{l})$ & $2.0 \pm 0.4$ & $2.1 \pm 0.6$ & 0.62 \\
Total VFA $(\mathrm{mmol} / \mathrm{l})$ & $37.1 \pm 3.9$ & $39.2 \pm 8.4$ & 0.18 \\
& $\ldots \ldots \ldots \ldots \ldots . . \mathrm{mol} \% \ldots \ldots \ldots \ldots \ldots \ldots .$. & \\
Acetate & $52.0 \pm 0.3^{\mathrm{a}}$ & $53.2 \pm 0.5^{\mathrm{b}}$ & 0.001 \\
Propionate & $20.9 \pm 0.9$ & $20.7 \pm 0.4$ & 0.25 \\
n-butyrate & $16.4 \pm 0.5$ & $16.4 \pm 0.2$ & 0.15 \\
i-butyrate & $0.7 \pm 0.1$ & $0.7 \pm 0.1$ & 0.08 \\
i-valerate & $4.4 \pm 0.5^{\text {a }}$ & $3.7 \pm 0.4^{\mathrm{b}}$ & 0.62 \\
n-valerate & $5.4 \pm 0.5$ & $5.3 \pm 0.4$ & 0.3 \\
\hline
\end{tabular}


Table 6: Effect of live yeast on fermentation parameters (Exp. 2)

\begin{tabular}{|lccc|}
\hline Items & Control & Live yeast & $\mathrm{P}$ \\
\hline $\mathrm{pH}$ & $6.51 \pm 0.05$ & $6.49 \pm 0.08$ & 0.3 \\
Redox potential (mv) & $-295.7 \pm 25$ & $-288.2 \pm 16$ & 0.08 \\
Gas volume (ml) & $1305 \pm 52^{\mathrm{a}}$ & $1080 \pm 81^{\mathrm{b}}$ & 0.02 \\
Ammonia $(\mathrm{g} / \mathrm{l})$ & $0.23 \pm 0.03$ & $0.17 \pm 0.03$ & 0.09 \\
& $0.51 \pm 0.09$ & $0.63 \pm 0.09$ & 0.08 \\
\hline Effluent PDM (g/l) & & & \\
\hline
\end{tabular}

${ }^{\mathrm{a}, \mathrm{b}}$ Means within a row with different superscripts are significantly different $(\mathrm{P}<005)$. $\mathrm{PDM}=$ particulate dry matter (microbial output)

Table 7: Effect of live yeast on rumen VFA and the molar \% VFA (Exp. 2)

\begin{tabular}{|lccc|}
\hline Acids & Control & Live yeast & $\mathrm{P}$ \\
\hline Acetate $(\mathrm{mmol} / \mathrm{l})$ & $19.1 \pm 5.1$ & $20.0 \pm 3.1$ & 0.4 \\
Propionate $(\mathrm{mmol} / \mathrm{l})$ & $8.8 \pm 2.6$ & $9.2 \pm 1.6$ & 0.51 \\
i-butyrate $(\mathrm{mmol} / \mathrm{l})$ & $0.3 \pm 0.1$ & $0.3 \pm 0.1$ & 0.09 \\
n-butyrate $(\mathrm{mmol} / \mathrm{l})$ & $5.5 \pm 1.6$ & $6.2 \pm 0.9$ & 0.54 \\
i-valerate $(\mathrm{mmol} / \mathrm{l})$ & $1.5 \pm 0.6$ & $1.73 \pm 0.6$ & 0.35 \\
n-valerate $(\mathrm{mmol} / \mathrm{l})$ & $2.3 \pm 0.8$ & $2.5 \pm .5$ & 0.22 \\
Total VFA $(\mathrm{mmol} / \mathrm{l})$ & $37.5 \pm 10.7$ & $40 \pm 6.7$ & 0.08 \\
& $\ldots \ldots \ldots \ldots \ldots \ldots \ldots \ldots .$. & \\
Acetate & $51.3 \pm 1.39$ & $50.1 \pm 1.0$ & 0.43 \\
Propionate & $23.4 \pm 0.8$ & $22.9 \pm 0.6$ & 0.2 \\
n-butyrate & $14.7 \pm 0.9$ & $15.6 \pm 0.5$ & 0.09 \\
i-butyrate & $0.8 \pm 0.1$ & $0.8 \pm 0.01$ & 0.67 \\
i-valerate & $3.8 \pm 0.6$ & $4.2 \pm 0.8$ & 0.32 \\
n-valerate & $6.0 \pm 0.4$ & $6.3 \pm 0.5$ & 0.24 \\
\hline
\end{tabular}


A

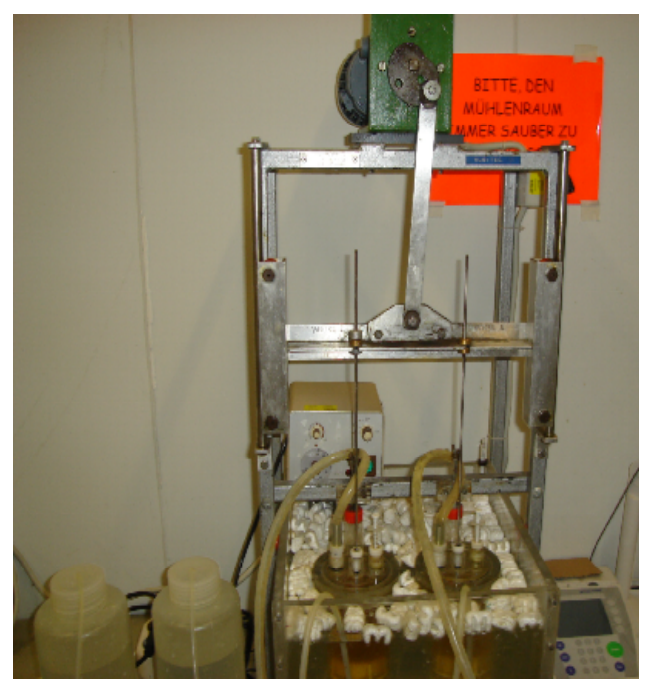

B

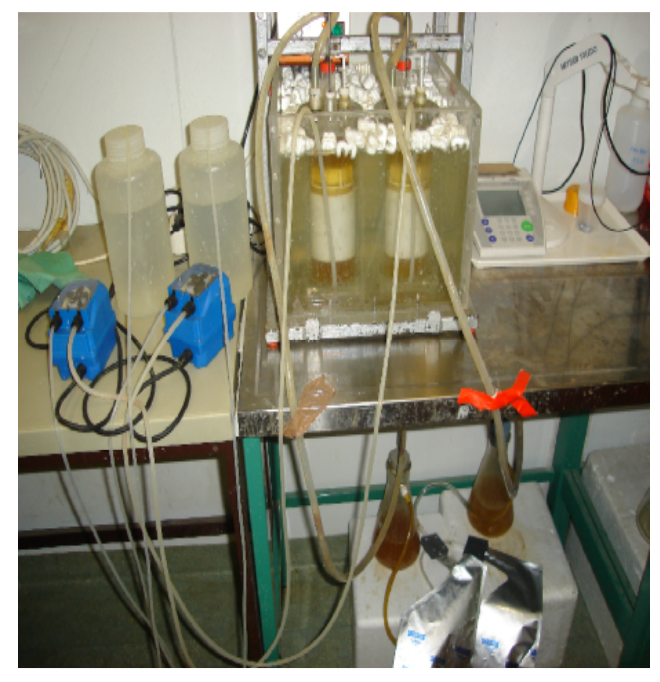

$\mathrm{C}$

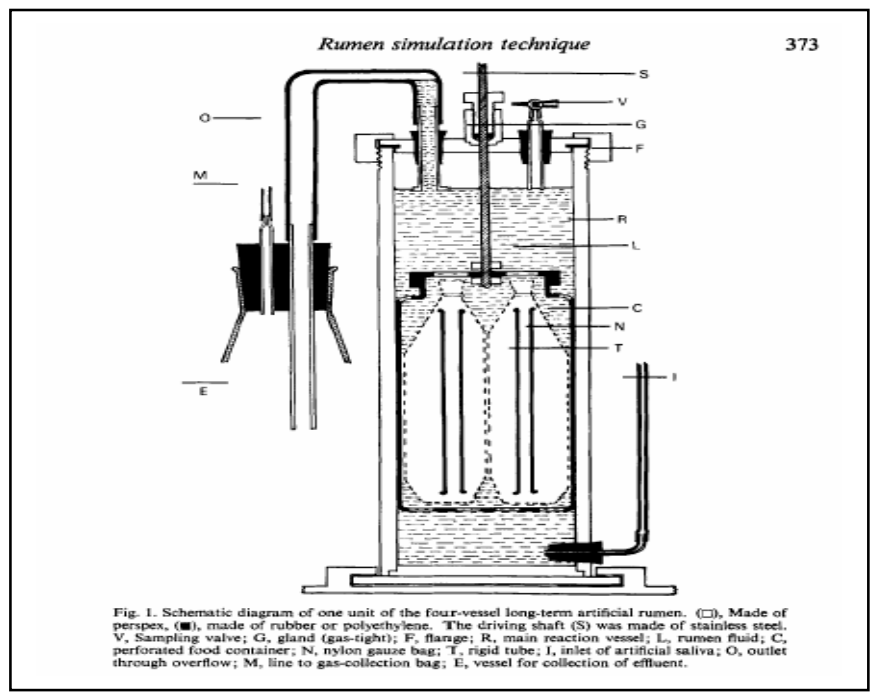

Fig. 1: A and B (Rusitec) Rumen Simulation technique design used in the experiment. C. Schematic diagram of one vessel of rusitec adapted from Czerkawski and Breckenridge (1977). 


\section{DISCUSSION}

In animals fed high-energy diets, decreased lactic acid concentrations are associated with higher ruminal $\mathrm{pH}$, and are characteristic of much more stable ruminal fermentation. These alterations in ruminal fermentations can be expected for improved digestion, and could also be reflected in improved intake. The ability of yeast to prevent the accumulation of lactic acid in the rumen suggests a role for viable yeast in overcoming ruminal dysfunctions associated with the use of high energy diets used in both high-producing dairy and fastgrowing beef cattle. The significant increase in acetate and numerical increase in some individual and total VFA by the addition of yeast culture was in agreement with results of Callaway and Martin, (1997) and Oeztuerk, (2009). They reported that yeast culture increased the concentrations of acetate and total volatile fatty acids that produced by Sel. ruminantium HD4 and increased the concentrations of propionate and total volatile fatty acids that produced by Sel. ruminantium H18. Callaway and Martin, (1997) suggested that, yeast culture provides soluble growth factors (i.e., organic acids, B vitamins, and amino acids) which stimulate growth of ruminal bacteria that utilize lactate and digest cellulose. So, dietary supplementation with yeast cultures that are high in these growth factors may improve ruminal fermentation. Moreover, Wallace and Newbold (1992) concluded that the production benefits seen when yeast culture is added to the diet arise from changes in the stoichiometry of VFA formation. The increase in the proportion of acetate was also observed by the experiment of Mutsvangwa et al. (1992) with yeast culture. The positive effect of living yeast cell in experiment 2 was in agreement with that of Dawson et al. (1990) and Callaway and Martin, (1997) who reported that heat inactivated yeast culture preparations have no effect on ruminal bacterial growth, suggesting that live yeast cells are necessary for the stimulation of growth of lactate utilizing bacteria Sel. ruminantium.

The decrease in gas production which is mainly methane is a promising result, because methane emissions represent losses of up to $15 \%$ of gross energy intake for forage-fed cattle and losses of $2-4 \%$ for cattle consuming diets rich in readily fermentable substates (Johnson and Johnson, 1995). There have been many attempts to manipulate the rumen fermentation with the intention of increasing the production of propionate and reducing the production of methane. There are advantages in both directions, since the production of methane 
represents a direct loss of energy while, propionic acid is an important precursor for gluconeogenesis. It can thus have a protein sparing role since amino acids are the other main source of glucose precursors (Leng, 1970).

In the current study, many of the changes associated with the addition of yeast cultures were marginal and often not statistically significant. This makes interpretation difficult, In conclusion, these results indicated that, the addition of either autoclaved or live yeast cultures stimulated ruminal fermentation and this effect was more pronounced with live yeast culture.

\section{REFERENCES}

Callaway, E.S. and Martin, S.A. (1997): Effects of a Saccharomyces cerevisiae culture on ruminal bacteria that utilize lactate and digest cellulose. Journal of Dairy Science, 80: No. 9.

Czerkawski J.W. and Breckenridge, G. (1977): Design and development of a long-term rumen simulation technique (Rusitec). Brit. J. Nutr. 38: 371-384.

Dawson, K.A.; Newman, K.E. and Boling, J.A. (1990): Effects of microbial supplements containing yeast and lactobacilli on roughage-fed ruminal microbial cativities. J. Anim. Sci. 68: 3392.

Gomez-Alarcon, R.A.; Dudas, C. and Huber, J.T. (1990): Influence of cultures of Aspergillus oryzae on rumen and total tract digestibility of dietary components. J. Dairy Sci. 73: 703.

Johnson, K.A. and Johnson, D.E. (1995): Methane emissions from cattle. J. Anim. Sci. 73: 2483-2492.

Leng, R.A. (1970): Glucose synthesis in ruminants. Adv. in Vet. Sci., 14: 209.

McDougall, E.I. (1948): Studies on ruminant saliva. 1. the composition and out put of sheep`s Saliva. Biochemical journal, 43, (1), 99.

Mutsvangwa, T.; Edwards, I.E.; Topps, J.H. and Peterson, G.F.M. (1992): The effect of dietary inclusion of yeast culture (YeaSacc) on patterns of rumen fermentation, food intake and growth of intensively fed bulls. Anim. Prod. 55: 35-40.

Newbold, C. J.; Wallace, R.J.; Chen, X.B. and McIntosh, F. (1995): Different strains of Saccharomyces cerevisiae differ in their effects on rumen fermentation both in vitro and in sheep. J. Anim. Sci. 73: 1811-1818. 
Newbold, C.J.; Wallace, R.J. and McIntosh, F. (1996): Mode of action of the yeast Sacchavomyces cerevisiae as a feed additive for ruminants. British Journal of 'Nutrition (1996), 76, 249-261

Nisbet, D.J. and Martin, S.A. (1991): The effect of Saccharomyces cerevisiae culture on lactate utilization by the ruminal bacterium Selenomonas ruminantium. J. Anim. Sci. 69: $4628-4633$.

Öztürk, H. (2003): In-vitro-Studien zum Einfl uss von Topinamburmehl und Saccharomyces boulardii auf den mikrobiellen Vormagenstoffwechsel. Dissertation, Tierärztliche Hochschule, Hannover (Germany), pp. 88.

Oeztuerk, H. (2009): Effects of live and autoclaved yeast cultures on ruminal fermentation in vitro. Journal of Animal and Feed Sciences, 18: 142-150.

Schäfer, K. (1995): Analysis of short chain fatty acids from different intestinal samples by capillary gas chromatography. Chromatographia, 40: 550-556.

Varga, G.A. and Kolver, E.S. (1997): Microbial and animal limitations to fiber digestion and utilization. J. Nutr. 127: 819S-823S.

Wallace, R.J. and Newbold, C.J. (1992): Probiotics for Ruminants. In: R. Fuller (Ed.) Probiotics: The Scientific Basis. p 317. Chapman and Hall, London. 